\title{
The National Credit Act's Remedies for Reckless Credit in the Mortgage Context
}

R Brits*

\section{P.E.R}

Pioneer in peer-reviewed, open access online law publications

Author

Reghard Brits

Affiliation

University of Pretoria

South Africa

Email reghard.brits@up.ac.za

Date of submission

28 July 2017

Date published

8 January 2018

Editor Dr A Gildenhuys

How to cite this article

Brits R "The National Credit Act's Remedies for Reckless Credit in the Mortgage Context" PER / PELJ 2018(21) - DOI

http://dx.doi.org/10.17159/17273781/2018/v21i0a2955

Copyright

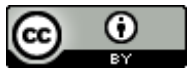

DOI

http://dx.doi.org/10.17159/17273781/2018/v21i0a2955

\begin{abstract}
The National Credit Act 34 of 2005 prohibits the granting of reckless credit and also provides for certain remedies that courts can grant to consumers who have fallen victim to reckless lending practices. Depending on the circumstances, these remedies are the partial or full setting aside of the consumer's rights and obligations under the agreement; the temporary suspension of the effect of the agreement; and the restructuring of the consumer's obligations. This article investigates these remedies with a focus on the effect that they would have on a credit provider under a mortgage agreement. The argument is made that the contractual and security rights of credit providers amount to "property" for the purposes of section 25(1) of the Constitution of the Republic of /South Africa, 1996 (the property clause) and that, to some degree or another, each of these remedies involves a "deprivation" (limitation or modification) of the creditor provider's rights (property). The consequence is that, when one of these remedies is granted to a consumer, the court must tailor the remedy in such a way that the effect on the credit provider is not "arbitrary" as meant in the property clause. Therefore, the proposal is that there must be a sufficient relationship between the purpose of the remedy (to discourage reckless lending and to rectify the damage caused) and the effects thereof on the credit provider. In general, the remedy should not go further than is necessary to rectify the prejudice suffered by the consumer due to the credit provider's conduct. The formulation of the remedy should accommodate considerations such as whether and to what extent either or both parties have already performed under the agreement, and it should accordingly ensure that the consumer will not be unjustifiably enriched. The remedy should also account for the effect that it would have if the consumer is permitted to keep the property that was subject to the reckless credit agreement. The article furthermore raises doubts regarding the recent high court judgment in $A B S A v$ De Beer 20163 SA 432 (GP), where all the consumer's rights and obligations under a mortgage agreement were set aside due to the credit provider's reckless conduct. Remedies like this have serious consequences and therefore it is imperative that courts carefully investigate all the effects that the order would have, so that a just and reasonable outcome is achieved. This article accordingly aims to provide some guidance with reference to the principles of constitutional property law.
\end{abstract}

\section{Keywords}

National Credit Act; reckless credit; remedies; mortgage; constitutional property law. 


\section{Introduction}

One of the aims of the National Credit Act is to promote responsibility in the credit market by encouraging responsible borrowing and discouraging reckless lending. ${ }^{2}$ When seeking to resolve consumer over-indebtedness through debt enforcement or debt restructuring, for instance, the Act also places a premium on the satisfaction of all responsible - as opposed to irresponsible - financial obligations. ${ }^{3}$ Therefore, one of the ways in which Parliament intended to address the problems surrounding consumer overindebtedness in South Africa was by providing ways to prevent people from incurring unaffordable debt but also to relieve or "rescue"4 consumers who have fallen victim to reckless lending.

The focus of this article is on the latter, namely the remedies that the NCA provides for consumers who have been exposed to what the Act calls "reckless credit". ${ }^{5}$ My focus is also narrowed to mortgage agreements in the light of the fact that the high court in $A B S A v D e B e r^{6}$ recently declared a mortgage agreement reckless and remedied the situation by setting aside all of the consumer's obligations under the agreement. ${ }^{7}$ Setting aside all the obligations under a mortgagee agreement, which is one of the available

Reghard Brits. BCom (Law) LLB LLD (Stellenbosch) Cert Insolvency Law \& Practice (Pretoria). Senior Lecturer, Department of Mercantile Law, University of Pretoria. Email: reghard.brits@up.ac.za. This article forms the basis of a paper presented at the annual South African Property Law Teachers' colloquium, hosted by Stellenbosch University on 2-3 November 2017. My gratitude to Corlia van Heerden for reading and commenting on this article. All shortcomings are my own.

National Credit Act 34 of 2005 (hereafter NCA).

Section 3(c) of the NCA.

Section $3(\mathrm{~g})$ and (i) of the NCA.

Vessio 2006 THRHR 657.

Sections 80-84 of the NCA. For situations in which these provisions do not apply, see ss 78(1)-(2). In general, see Van Heerden "Over-indebtedness and Reckless Credit" para 11.5; Otto and Otto National Credit Act Explained 4th ed 89-92; KellyLouw "Consumer Credit" paras 135-137; Kelly-Louw Consumer Credit Regulation 293-313. Also see Coetzee Comparative Reappraisal270-282; Kelly-Louw 2014 SA Merc LJ 26-45; Brits Mortgage Foreclosure para 4.3.3; Stoop and Kelly-Louw 2011 PELJ 85-88; Renke 2011 THRHR 223-227; Van Heerden and Boraine 2011 De Jure 392-415; Boraine and Van Heerden 2010 THRHR 650-656; Stoop 2009 SA Merc LJ 367-368; Vessio 2009 TSAR 274-289; Kelly-Louw 2008 SA Merc LJ 218-222; Renke, Roestoff and Haupt 2007 Obiter 245-247; Vessio 2006 THRHR 649-657.

$6 \quad$ ABSA Bank Ltd v De Beer 20163 SA 432 (GP) (hereafter De Beer). See Van Heerden "Over-indebtedness and Reckless Credit" para 11.5.7.1; Koekemoer 2016 $J Q R$ para 2.1.

7 Similar situations have been reported in the media. See eg SAPA 2010 http://www.fin24.com/PersonalFinance/Money-Clinic/Absa-guilty-of-reckless-

lending-20100430; and also Kelly-Louw Consumer Credit Regulation 312-313; Kelly-Louw 2010 JQR para 2.1; Boraine and Van Heerden 2010 THRHR 651. 
orders that a court may grant, seems rather drastic, ${ }^{8}$ and thus it is vital to closely analyse the law in this respect. The logical effects of such an order include that the property is set free of the mortgage (as a real security right) ${ }^{9}$ while the consumer (the owner/mortgagor) is no longer required to pay anything towards the loan. One may ask whether this kind of windfall for the victim of reckless lending is truly defendable. In reaction to the order that was granted in De Beer, authors like Sonnekus ${ }^{10}$ and Otto ${ }^{11}$ have expressed their concerns as to the extent of the court's powers in this regard. Other authors have also pointed to the serious uncertainties that surround these remedies in general. ${ }^{12}$

During the years that the NCA has been in operation, it has become quite common for consumers to make the allegation of reckless lending as one of their defences in proceedings instituted by the credit provider to enforce the credit agreement. Except for De Beer ${ }^{13}$ such defences have rarely been successful in both the mortgage ${ }^{14}$ and non-mortgage ${ }^{15}$ contexts, although

8 See eg Vessio 2006 THRHR 657; Vessio 2009 TSAR 288.

9 This is a consequence of the principle that the mortgage is accessory to the principal obligation - meaning that the security right cannot exist if there is no principal obligation. See eg Kilburn v Estate Kilburn 1931 AD 501 505-506; Thienhaus v Metje \& Ziegler 19653 SA 25 (A) 32; and further Brits Real Security 20-25. Sonnekus 2016 TSAR 351-361.

Otto 2017 TSAR 168-170.

12 See especially Van Heerden "Over-indebtedness and Reckless Credit" para 11.5.7; Van Heerden and Boraine 2011 De Jure 392-415; Boraine and Van Heerden 2010 THRHR 650-656.

13 And some matters reported in the media, as indicated in fn 7 above.

14 See eg Standard Bank of South Africa Ltd v Kelly 2011 ZAWCHC 1 (25 January 2011) (hereafter Kelly); Mercantile Bank Ltd v Hajat 2013 ZAGPJHC 134 (9 May 2013); ABSA Bank Ltd v Malherbe 2013 ZAFSHC 78 (16 May 2013); Land \& Agricultural Development Bank of South Africa Ltd v Bosch 2014 ZAGPJHC 130 (30 May 2014); ABSA Bank Limited v Pereira 2015 JDR 1208 (GJ); Standard Bank of South Africa Limited v Dlamini 2016 ZAGPPHC 26 (22 January 2016); ABSA Bank Limited v Kganakga 2016 ZAGPJHC 59 (18 March 2016); Nedbank Limited v Schoeman 2016 ZAGPJHC 142 (2 June 2016); Maria v Nedbank Limited; In re: Nedbank Limited v Foley 2016 ZAGPPHC 669 (4 August 2016); ABSA Bank Limited $v$ Potgieter 2017 ZAECPEHC 8 (31 January 2017); Wiese v ABSA Bank Limited 2017 ZAWCHC 12 (24 February 2017); FirstRand Bank Limited v Van Coller 2017 ZAGPPHC 85 (8 March 2017).

15 See eg SA Taxi Securitisation (Pty) Ltd v Mbatha and Two Similar Cases 20111 SA 310 (GSJ) (hereafter Mbatha); SA Taxi Securitisation (Pty) Ltd v Nako 2010 ZAECBHC 4 (8 June 2010) (hereafter Nako); SA Taxi Securitisation (Pty) Ltd v Xolile 2012 JOL 29510 (ECM); SA Taxi Securitisation (Pty) Ltd v Campher 2012 ZAECGHC 9 (24 February 2012) (hereafter Campher); SA Taxi Development Finance (Pty) Ltd v Mokolobe 2013 ZAGPJHC 198 (11 June 2013); Mofuta v SA Taxi Securitisation (Pty) Ltd, In re: SA Taxi Securitisation (Pty) Ltd v Mofuta 2013 ZAFSHC 95 (20 June 2013); SA Taxi Securitisation (Pty) Ltd v Melaphi 2014 ZAWCHC 47 (2 April 2014); Africa Bank Limited v Greyling 2014 ZAGPJHC 315 (7 November 2014); Toyota Financial Services South Africa v Mohlabi 2015 ZAFSHC 178 (10 September 2015) (hereafter Mohlabi). 
there have been some instances in which an application for summary judgment was denied due to the prospect that a reckless credit defence might succeed on trial. ${ }^{16}$ The lack of success in relying on reckless lending as a defence is mostly because consumers struggle to prove that the credit provider did not do a pre-agreement affordability assessment. Often the reckless credit defence is also raised as a last desperate attempt to thwart the credit provider's enforcement action, but the courts have little sympathy for vague and bold allegations of reckless lending without sufficient substantiation. ${ }^{17}$

Therefore, the aim of this article is to investigate the effect of the NCA's reckless credit remedies, with an emphasis on the mortgage context. It is imperative to establish clearer guidelines on how to approach these remedies, so that they can be applied in a consistent and principled manner. It is also necessary to comply with the overall purpose of the Act, which is to strike an equitable balance between the interests of consumers and credit providers. ${ }^{18}$ In this regard, the main proposal of this article is that section 25(1) of the Constitution of the Republic of South Africa, which prohibits the arbitrary deprivation of property, can be a useful tool to help evaluate the nature, effects and limits of the reckless credit remedies. I will show that the creditor's contractual right to receive payment in accordance with the terms of the contract, qualifies as "property" for constitutional purposes, and that the various remedies in the reckless credit context have the effect of "depriving" the credit provider of such property. Ultimately I will therefore argue that the arbitrariness test laid down in section 25(1) provides valuable insights into the application of these remedies. A general hypothesis is that any remedy given in the reckless credit context should be tailored in a way that it does not go further than what is necessary to rectify the prejudice caused to the consumer by the credit provider's reckless lending practice. Any interference with the credit provider's rights beyond this point is constitutionally suspect and should hence be avoided.

16 See eg ABSA Bank $v$ Coe Family Trust 20123 SA 184 (WCC); Benade v ABSA Bank Limited 2014 ZAWCHC 84 (16 May 2014); ABSA Bank Ltd v Schneider 2015 ZAGPPHC 855 (3 December 2015).

17 See eg Mbatha para 26; Mohlabi paras 13, 20.

18 Section 3 of the NCA. 


\section{Statutory framework for reckless credit}

\subsection{General}

The NCA prohibits a credit provider from entering into a reckless credit agreement with a prospective consumer. ${ }^{19}$ Therefore, before concluding a credit agreement, the credit provider must take reasonable steps to assess the proposed consumer's "general understanding and appreciation of the risks and costs of the proposed credit, and of the rights and obligations of a consumer under a credit agreement"; the consumer's "debt re-payment history as a consumer under credit agreements"; and his "existing financial means, prospects and obligations". ${ }^{20}$ The credit provider must furthermore assess "whether there is a reasonable basis to conclude that any commercial purpose may prove to be successful, if the consumer has such a purpose for applying for that credit agreement". ${ }^{21}$ The Act allows a credit provider to determine its own evaluative mechanisms or models and procedures when fulfilling its assessment obligations, as long as these are fair, objective and not in conflict with any affordability assessment regulations. ${ }^{22}$

However, the burden is not on the credit provider alone, since the Act expects the consumer, when applying for credit and while such an application is being considered, to "fully and truthfully answer any requests for information made by the credit provider as part of the assessment". ${ }^{23}$ Moreover, in the event that an allegation of reckless credit is made, it is as a complete defence for the credit provider if it can show that the consumer failed to fully and truthfully answer the relevant requests for information, and if such failure materially affected the credit provider's ability to make a proper assessment. ${ }^{24}$

Section 81 (3) of the NCA.

Section 81 (2)(a)(i)-(iii) of the NCA.

Section $81(2)$ (b) of the NCA.

Section 82(1) of the NCA. On the affordability assessment regulations, see Renke 2015 LitNet 432-454. Also see Van Heerden "Over-indebtedness and Reckless Credit" para 11.5.6; Van Heerden and Renke 2015 Int Insolv Rev 67-95; Kelly-Louw "Consumer Credit" para 135.

$23 \quad S$ 81(1).

24 S 81(4)(a)-(b). See Kelly-Louw 2014 SA Merc LJ 47-54; Kelly-Louw Consumer Credit Regulation 300-304; Kelly-Louw "Consumer Credit" para 136; Van Heerden "Over-indebtedness and Reckless Credit" para 11.5.5. 
Section 130(4)(a) of the Act determines that if, during any proceedings involving debt, a court determines that the credit agreement was reckless, ${ }^{25}$ the court "must" make one of the orders in section 83 pertaining to the reckless credit remedies. ${ }^{26}$ This appears to suggest that the court has no discretion to deviate from the powers granted in section 83 and that it can make no order other than those provided for in that section. ${ }^{27}$ Yet section 83 itself appears to incorporate a discretion by stating that the court or Tribunal ${ }^{28}$ "may" declare the agreement reckless..$^{29}$ In my view this implies that, even if all the conditions are met, the court is not obliged to declare the agreement reckless. ${ }^{30}$ As seen below, the possible orders are also discretionary, so even if it declares the agreement reckless, it seems that the court may - depending on the circumstances - decide not to grant a remedy.

Regarding the legal status of a reckless credit agreement, the Act does not classify it as unlawful and thus ab initio null and void. ${ }^{31}$ This is confirmed by the fact that reckless credit agreements are not included in the Act's general list in section 89 of credit agreements that are unlawful. ${ }^{32}$ Consequently, it seems clear that the intention is that such agreements remain valid, but that the courts are granted special powers to decide on the effects of such agreements. ${ }^{33}$ It should also be noted that a reckless credit agreement is not voidable and accordingly none of the remedies involve the setting aside of the agreement as such. ${ }^{34}$

25 When a court must determine whether credit was granted recklessly, it must consider the situation at the time when the agreement was made and not the situation when the determination is being made. See section 80(2) of the NCA.

26 Sections $130(4)$ (a) read with ss 80 and 83 of the NCA.

27 Van Heerden and Boraine 2011 De Jure 401; Kelly-Louw "Consumer Credit" para 137 fn 3.

28 Originally only a court had these powers, but s 25 of the National Credit Amendment Act 19 of 2014 has extended these powers to the Tribunal. Section 83(1) of the NCA. The court may exercise this power of its own accord (mero motu): see Van Heerden "Over-indebtedness and Reckless Credit" para 11.5.7; Otto and Otto National Credit Act Explained 4th ed 90; Boraine and Van Heerden 2010 THRHR 651; Van Heerden and Boraine 2011 De Jure 400-401. See Kelly para 8. However, also see University of Stellenbosch Legal Aid Clinic v Minister of Justice and Correctional Services 20166 SA 596 (CC) para 49, where in arguably an obiter dictum - the Constitutional Court did not regard there to be such a discretion. Boraine and Van Heerden 2010 THRHR 650-651, 655. Also see Van Heerden "Over-indebtedness and Reckless Credit" para 11.5.7.1. Boraine and Van Heerden 2010 THRHR 650, 651; Van Heerden and Boraine 2011 De Jure 401. Boraine and Van Heerden 2010 THRHR 652. 


\subsection{The reckless credit remedies}

The NCA essentially provides for three categories of reckless credit, each having its own consequences, namely the specific orders or remedies that can be granted - although there is some overlap. ${ }^{35}$

\subsubsection{Categories one and two}

In the first category of reckless credit, the agreement will be reckless if the credit provider failed to conduct the assessment referred to above, irrespective of what the outcome of such an assessment might have been at the time..$^{36}$ The second category is if the credit provider did make the required assessment but "entered into the credit agreement with the consumer despite the fact that the preponderance of information available to the credit provider indicated that the consumer did not generally understand or appreciate the consumer's risks, costs or obligations under the proposed credit agreement". ${ }^{37}$

Under both categories the court or Tribunal has a discretion to make either of the following two orders: ${ }^{38}$

(1) an order "setting aside all or part of the consumer's rights and obligations under that agreement, as the court determines just and reasonable in the circumstances" (henceforth referred to as the "setting-aside remedy"; or

(2) an order "suspending the force and effect of that credit agreement" until a date determined by the court when the order of suspension is made (henceforth referred to as the "suspension remedy").

A preliminary question is whether the court can grant both remedies by, for instance, setting aside a portion of the debt as well as suspending the repayment of the remaining portion? The NCA seems to insist on a choice between the two and does not appear to allow a combination. This is unfortunate, since it is conceivable that a combination of the remedies could be a feasible solution under certain circumstances.

See generally Boraine and Van Heerden 2010 THRHR 651-652; Van Heerden and

Boraine 2011 De Jure 393-394. Also see Kelly-Louw "Consumer Credit" para 137.

36 Section $80(1)$ (a) read with $\mathrm{s} 81$ (2) of the NCA.

37 Section $80(1)$ (b)(i) read with s 81 (2) of the NCA.

38 Section 83(2)(a)-(b) read with s 83(3)(b)(i) of the NCA. 
The Act does not say anything more on the details of the setting-aside remedy, but it does provide more information on the suspension remedy. It stipulates that, during the period of suspension, "the consumer is not required to make any payment required under the agreement"; "no interest, fee or other charge under the agreement may be charged to the consumer"; and "the credit provider's rights under the agreement, or under any law in respect of that agreement, are unenforceable, despite any law to the contrary". ${ }^{39}$ Therefore, the credit provider's penalty lies therein that, during this period, it will not receive any payment in respect of the agreement, that it will forfeit interest and other charges that would have accrued, and that it will not be able to enforce the agreement and repossess any property. ${ }^{40}$ In effect, a payment moratorium is created during the suspension period, but the consumer remains indebted to the credit provider. ${ }^{41}$ The apparent purpose of the suspension is to assist the consumer to eventually repay the debt. $^{42}$

The Act also provides that, when the suspension ends, all the rights and obligations of the credit provider and consumer are "revived" and "fully enforceable except to the extent that a court may order otherwise". 43 However, the Act stresses that, after the suspension ends, the credit provider may not retrospectively charge the consumer for any interest, fee or other charge that it could not charge during the suspension period. ${ }^{44}$ It can be mentioned in passing that there appears to be somewhat of a contradiction here. ${ }^{45}$ Although the Act states that all the rights and obligations will revive and will thus be fully enforceable after the suspension ends, this notion of a full revival of all rights and obligations of the parties is a misnomer and should not be taken literally, since it is not true that all rights become fully enforceable once more. Indeed, this principle - stated in seemingly absolute terms ("all" and "fully") - is significantly curtailed by the rule that no liability accrues on the consumer's part for interest et cetera during the suspension period. Fortunately, this contradiction is relatively minor and hopefully will have little practical implication. The legislature probably merely meant to convey the intention that, after suspension, the

\footnotetext{
39 Section 84(1)(a)-(b) of the NCA. See Mbatha para 48.

$40 \quad$ Van Heerden and Boraine 2011 De Jure 405.

41 Boraine and Van Heerden 2010 THRHR 654.

42 Boraine and Van Heerden 2010 THRHR 654.

43 Section 84(2)(a)(i)-(ii) of the NCA. The fact that the court may order otherwise seems to suggest that a further suspension is possible after the first one ends, but this is unclear: see Boraine and Van Heerden 2010 THRHR 654, 656.

44 Section $84(2)(b)$ of the NCA.

45 My gratitude to one of the anonymous reviewers who pointed this contradiction out to me and suggested that I briefly address it.
} 
contractual relationship between the parties will go ahead as normal but that, when it comes to calculating the consumer's liability, the suspension period (and the costs that would have accrued during this time) are, as it were, erased from memory.

Regarding the setting-aside remedy, the NCA says nothing more than that it can be done in part or in full and, importantly, that the order must be just and reasonable in the circumstances. In Standard Bank $v$ Kelly ${ }^{46}$ the court advised that the decision "will in general be informed by the statute's policy of promoting equity in the credit market and by the consideration of assisting the consumer to fully repay responsibly undertaken debt at the expense, if necessary and appropriate, of subordinating the rights of reckless creditors".

In SA Taxi Securitisation $v$ Mbatha ${ }^{47}$ the court suggested that the settingaside remedy involves the setting aside of the agreement itself and thus that "the agreement would be null and void, and as if it had never been". 48 However, a careful reading of the Act does not reveal this consequence, since nothing in the Act suggests that the agreement is void. Moreover, the NCA does not empower the court to set aside the agreement in the sense of its being voidable, but instead the court may merely set aside all or part of the rights and obligations of the consumer. ${ }^{49}$ The Act does not mention the rights and obligations of the credit provider, but the reciprocal nature of the contract implies that, if the rights and obligations of the consumer are set aside, the countervailing rights and obligations of the credit provider must logically also fall away. ${ }^{50}$

It is worth highlighting that a suspension or setting aside may follow for the first two categories of reckless credit even if the consumer is not overindebted at the time the matter is adjudicated. ${ }^{51}$ However, it is arguable that over-indebtedness should nevertheless always be a factor when deciding on which remedy to grant, since the remedy should generally be focussed on rectifying any negative consequences of the reckless loan and should not lead to an unjustified windfall for the consumer.

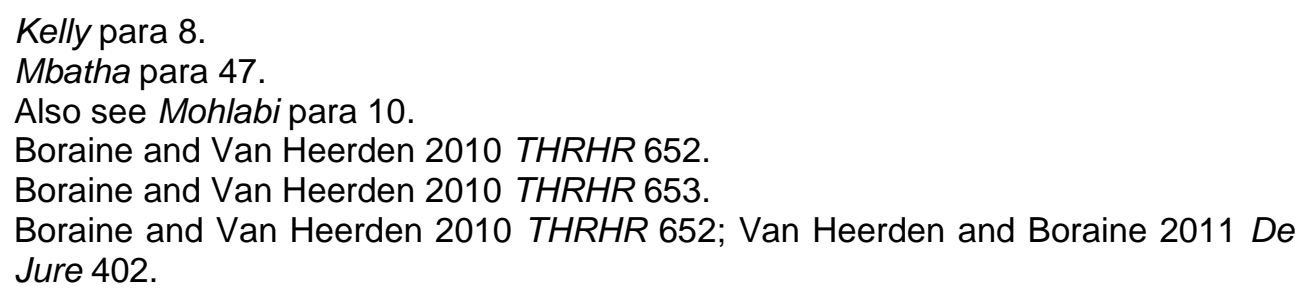




\subsubsection{Category three}

The third category of reckless credit is if the credit provider did make the required assessment, but "entered into the credit agreement with the consumer despite the fact that entering into that credit agreement would make the consumer over-indebted". ${ }^{2}$ In this situation, the court or Tribunal "must further consider whether the consumer is over-indebted at the time of those proceedings" and if it is concluded that the consumer is indeed overindebted, the court or Tribunal has the discretion to make an order: 53

(1) "suspending the force and effect of that credit agreement until a date determined by the Court when making the order of suspension"; and

(2) "restructuring the consumer's obligations under any other credit agreements".

Before making such an order, the court or Tribunal must consider "the consumer's current means and ability to pay the consumer's current financial obligations that existed at the time the agreement was made" as well as "the expected date when any such obligation under a credit agreement will be fully satisfied, assuming the consumer makes all required payments in accordance with any proposed order". 54

Moreover, the restructuring must be done in accordance with the magistrates' courts powers to rearrange a consumer's obligations as part of the debt review process. ${ }^{55}$ Hence, the consumer's obligations can be rearranged by: 56

(1) "extending the period of the agreement and reducing the amount of each payment due accordingly";

52 Section $80(1)$ (b)(ii) read with s 81(2) of the NCA. S 88(4) seemingly provides for a fourth category: "If a credit provider enters into a credit agreement, other than a consolidation agreement contemplated in this section, with a consumer who has applied for a debt re-arrangement and that re-arrangement still subsists, all or part of that new credit agreement may be declared to be reckless credit, whether or not the circumstances set out in section 80 apply." As Boraine and Van Heerden 2010 THRHR 652 point out, no consequences are ascribed to this category. Sections 83(3)(a) and (b)(i)-(ii) of the NCA. See further Van Heerden "Overindebtedness and Reckless Credit" para 11.5.7.2.

$54 \quad$ Section $83(4)(a)-(b)$ of the NCA.

55 Section 83(3)(b)(ii) read with $\mathrm{s} 87$ of the NCA.

56 Section $87(1)($ b)(ii) read with s $86(7)$ (c)(ii)(aa)-(dd) of the NCA. 
(2) "postponing during a specified period the dates on which payments are due under the agreement";

(3) "extending the period of the agreement and postponing during a specified period the dates on which payments are due under the agreement"; or

(4) "recalculating the consumer's obligations because of contraventions of Part A or B of Chapter 5, or Part A of Chapter 6".

\subsubsection{Summary}

Accordingly, depending on the kind of reckless credit involved, the court or Tribunal may:

(1) set aside the consumer's rights and obligations in part or in full, in accordance with what would be just and reasonable;

(2) suspend the force and effect of the agreement for a certain period; or

(3) suspend the force and effect of the agreement for a certain period plus restructure any of the consumer's other obligations.

When considering the different categories of reckless credit, it is apparent that the setting-aside remedy is not available for the third category, and that the restructuring remedy is not available for the first two categories. Suspension alone is also not possible for the third category, since it must be combined with a restructuring order. It is not clear why the legislature took this approach. On what basis should a setting-aside remedy not be available for the third category? And why should a restructuring order not be available for the first two categories? To my mind it would have been simpler to make all the remedies available in each instance, and then leave it up to the courts to exercise a proper discretion. It would also have been useful if the "just and reasonable" standard was required for each of the remedies and not for the setting-aside remedy only.

It can be mentioned that, notwithstanding what category the situation falls into, if the consumer can convincingly allege his over-indebtedness, the court is permitted to grant relief in the form of a debt rearrangement order. ${ }^{57}$

57 Section $85(\mathrm{~b})$ read with s 87 of the NCA. 
Therefore, the usual debt rearrangement remedy is, when appropriate, available as an alternative option.

One should also consider that the granting of reckless credit qualifies as prohibited conduct under the NCA, and hence the Tribunal may impose an administrative fine on a credit provider who has engaged in such behaviour. ${ }^{58}$ If a credit provider repeatedly fails to comply with the Act, the Tribunal may also suspend or cancel its registration as a credit provider. ${ }^{59}$

\subsection{Some of the major uncertainties surrounding the remedies}

Several uncertainties surround the application of these remedies, and authors like Boraine and Van Heerden have analysed these in detail. ${ }^{60}$ In what follows I summarise the three most pressing uncertainties. Further below, I argue that a constitutional perspective may help to answer some of these doubts.

\subsubsection{Uncertainty one}

The first uncertainty is that it is not clear how a court should exercise its discretion when it comes to the choice between the setting-aside and suspension remedies. Also, if the court chooses the setting-aside remedy, how should it decide between setting it aside in part or in full? ${ }^{61}$ Van Heerden and Boraine provide some suggestions in this regard, but it is not necessary to repeat these here. ${ }^{62}$ Further below, I add my suggestions in this regard.

\subsubsection{Uncertainty two}

A second difficulty with the remedies is that the Act does not distinguish between the situations where the parties merely entered into the reckless credit agreement and those where either or both of them have already

\footnotetext{
58 Section 151 of the NCA.

59 Section 57 of the NCA.

60 Boraine and Van Heerden 2010 THRHR 651, 652-656; Van Heerden and Boraine 2011 De Jure 402-408, 414-415; Van Heerden "Over-indebtedness and Reckless Credit" para 11.5.7.1.

61 Boraine and Van Heerden 2010 THRHR 651, 652; Van Heerden and Boraine 2011 De Jure 402-403, 414-415; Van Heerden "Over-indebtedness and Reckless Credit" para 11.5.7.1. indebtedness and Reckless Credit" para 11.5.7.1.
} 
performed in terms of the agreement. ${ }^{63}$ This is not really a problem for the suspension, restructuring or partial setting-aside remedy, since the contractual relationship between the parties will continue - either as normal after the suspension ends, or in accordance with the restructured or reduced obligations of the consumer.

Also, the matter seems relatively uncomplicated in instances where neither of the parties have performed yet and the obligations of the consumer are set aside in full. This would effectively amount to a cancellation of the agreement - it would end the credit relationship and absolve the parties from further reciprocal performance. ${ }^{64}$ However, what would be the situation if either or both parties have performed (either in full or in part) and the consumer's obligations are set aside in full? Can the credit provider reclaim any moneys advanced or property delivered to the consumer, and can the consumer reclaim any payments made to the credit provider? ${ }^{65}$

Boraine and Van Heerden argue that, because section 83(2)(a) refers to the setting aside of rights and obligations "under that agreement", there is no restriction on the credit provider's ability to claim money or goods in terms of another cause of action, such as unjustified enrichment. ${ }^{66}$ The Act also does not expressly oust any other causes of action. ${ }^{67}$ Boraine and Van Heerden thus contend that the parties should be able to reclaim at least some of what they have performed. ${ }^{68}$ In this respect, Sonnekus has also argued that the credit provider should have a claim in unjustified enrichment against the consumer. ${ }^{69}$ Further below, I make a suggestion based on constitutional property law.

\subsubsection{Uncertainty three}

A third question is: what should happen to the property that is subject to the reckless credit agreement? When it comes to movable property that is

63 Boraine and Van Heerden 2010 THRHR 652; Van Heerden and Boraine 2011 De Jure 402. Also see Van Heerden "Over-indebtedness and Reckless Credit" para 11.5.7.1.

64 Boraine and Van Heerden 2010 THRHR 653; Van Heerden and Boraine 2011 De Jure 403. Also see Van Heerden "Over-indebtedness and Reckless Credit" para 11.5.7.1. Boraine and Van Heerden 2010 THRHR 653; Van Heerden and Boraine 2011 De Jure 403. Boraine and Van Heerden 2010 THRHR 653; Van Heerden and Boraine 2011 De Jure 403, 415. Also see Van Heerden "Over-indebtedness and Reckless Credit" para 11.5.7.1.

67 Boraine and Van Heerden 2010 THRHR 656.

68 Boraine and Van Heerden 2010 THRHR 655, 656.

69 Sonnekus 2016 TSAR 361. 
subject to a lease or instalment agreement, this issue is particularly thorny because, in most instances, the credit provider would have reserved ownership until the debt is fully paid. ${ }^{70}$ In cases of restructuring or partial setting aside, the answer is relatively straightforward, since the consumer would simply remain in possession as normal while the remaining debt is being paid off or while the restructured payment plan is being completed. In the event of a full setting aside of the consumer's obligations, it has been suggested that "the credit provider, who remains the owner of the vehicle, would be entitled to restoration of the vehicle". ${ }^{71}$

In cases where the effects of a lease or instalment agreement pertaining to movable property are suspended, it is particularly difficult to determine what should happen with the property. ${ }^{72}$ Boraine and Van Heerden refer to two possible answers. The first option is that the movable property should remain with the consumer during the period of suspension. The reasons for this theory include: the enforcement of the agreement (including the credit provider's right to repossess the property) is barred during suspension; the consumer is under no express duty to return the property for the period of the suspension; and the agreement is not cancelled or set aside. ${ }^{73}$

The second option is that the property should be returned to the credit provider during the suspension period. This theory is based on the goal of the Act to balance the rights of consumers and credit providers, which arguably renders it unfair to allow the consumer to retain the credit provider's depreciating security while not having to make any payments. ${ }^{74}$ The second option has found support in case law ${ }^{75}$ and is also the one favoured by Van Heerden and Boraine. ${ }^{76}$

Even so, there remains doubt regarding effect of especially a suspension order on movable property that is subject to a lease or instalment agreement, but for present purposes the focus is on mortgage agreements, so it is not necessary to express a concrete view. That being said, the arguments I make below regarding the impact of section $25(1)$ of the

70 See the definitions of "instalment agreement" and "lease" in s 1 of the Act.

71 Mbatha para 47. Also see SA Taxi Securitisation (Pty) Ltd v Chesane 20106 SA 557

(GSJ) para 28; Nako para 29; SA Taxi Securitisation (Pty) Ltd v Xolile 2012 JOL 29510 (ECM) para 24; Campher para 15.

72 Van Heerden and Boraine 2011 De Jure 405.

73 Van Heerden and Boraine 2011 De Jure 405.

74 Van Heerden and Boraine 2011 De Jure 406, 407.

75 Mbatha paras 45-48, 55; Nako para 29.

76 Van Heerden and Boraine 2011 De Jure 407, 415. Also see Van Heerden "Overindebtedness and Reckless Credit" para 11.5.7.1. 
Constitution on the formulation of these remedies, will perhaps shed some light in the movable context too.

In the case of mortgage agreements, it is trite that the consumer remains the owner of the immovable property, while the credit provider holds a limited real right in the property as security until the debt is discharged. ${ }^{77}$ In these cases, the full setting aside of the consumer's obligations will naturally have the effect that the real security right extinguishes, which is a consequence of the accessoriness principle. ${ }^{78}$ Neither a partial setting aside nor a suspension will have this effect, and thus the credit provider's security will remain intact for the remaining portion of the debt or will become enforceable again once the suspension period ends. In none of these instances will the consumer lose his ownership of the property, and none of the reckless credit remedies permit a sale in execution of the property. Also, there is no basis upon which the creditor can temporarily dispossess the consumer during the suspension period.

This outcome may seem unfair in some mortgage cases. For instance, a full setting aside will mean that the property is totally freed of the mortgage while the consumer does not have to pay anything more toward the loan. The benefit enjoyed by the consumer and the attendant losses experienced by the credit provider may sometimes seem out of proportion compared to the damage inflicted on the consumer by the credit provider's reckless lending conduct. Below, I explain with reference to section 25(1) of the Constitution that the content of any remedy must be designed to ensure that there is a proper level of proportionality between the purpose of the remedy and the effects thereof.

\section{The property clause and reckless credit}

\subsection{General}

The general purpose of constitutional property law is to achieve a balance between the protection of vested rights and the promotion of the public interest in regulating the use of property. ${ }^{79}$ To this end, section 25(1) of the Constitution (the property clause) provides that no one may be deprived of

\footnotetext{
77 The same is true for movables under a secured loan or pawn transaction.

78 Boraine and Van Heerden 2010 THRHR 653.

79 First National Bank of SA Ltd t/a Wesbank v Commissioner, South African Revenue Service; First National Bank of SA Ltd t/a Wesbank v Minister of Finance 20024 SA 768 (CC) (hereafter FNB) para 50; Van der Walt Constitutional Property 100-101; Mostert and Badenhorst "Property" para 3FN6.2.2; Roux "Property" para 46.1.
} 
property except in terms of law of general application and that no law may permit the arbitrary deprivation of property. ${ }^{80}$ Arguably, this constitutional norm can find useful application in the context of the NCA's remedies for reckless lending. There are at least three important questions revealed by section 25(1) for the present purposes: Does the creditor's right to receive payment under the credit agreement qualify as "property"? Do the remedies involve a "deprivation" of such property? And is this deprivation of property "arbitrary"?

\subsection{Creditors' rights as "property"}

In the case of a mortgage agreement, the creditor primarily has two kinds of rights: first the personal claim for the repayment of the loan in accordance with the terms of the contract, and secondly the accessory real security right of mortgage. The question is whether these rights qualify as "property" for constitutional purposes?

The Constitution does not define "property" but states that "property is not limited to land", 82 which at least implies that property includes land. The Constitutional Court has also confirmed that land and corporeal movables are at the heart of the concept of property. ${ }^{83}$ However, nowhere does the Constitution limit the concept to tangible assets, and accordingly commentators accept that the property concept should be interpreted generously to include, for instance, economically significant intangible assets. $^{84}$

Classifying a mortgage as property is relatively straightforward. A mortgage is a limited real right in tangible immovable property, and hence the right of mortgage itself is commonly regarded as incorporeal immovable property. ${ }^{85}$

80 On the property clause in general, see Van der Walt Constitutional Property; Roux and Davis "Property" ch 20; Mostert and Badenhorst "Property" ch 3FB; Badenhorst, Pienaar and Mostert Law of Property ch 21; Roux "Property" ch 46. Ss 25(2)-(9) of the Constitution deals with expropriation and land reform. These matters fall outside the scope of this article, as they do not relate to reckless credit.

81 The methodology for deciding a s 25 case was first established in FNB para 46. For the present purposes it is not necessary to fully explain the methodology or to go through every step. See further Roux "Property" para 46.1.

82 Section 25(4)(b) of the Constitution.

$83 \quad F N B$ para 51

$84 \quad$ Van der Walt Constitutional Property 93, 114; Roux "Property" para 46.3(b); Roux and Davis "Property" para 20.3; Mostert and Badenhorst "Property" para 3FB6.1.2.

85 Badenhorst, Pienaar and Mostert Law of Property 36. 
Since "property" includes rights in property, ${ }^{86}$ such as limited real rights, ${ }^{87}$ it is not controversial therefore that a mortgage, as a real security right, qualifies as "property" for the purposes of section 25(1). ${ }^{88}$

The credit provider's claim for the repayment of the loan is more complex, since this personal right is neither a traditional object of property nor a right in property. Notwithstanding, there is strong support in academic scholarship for the prospect that a contractual right with a monetary value (an incorporeal thing) qualifies as "property" for constitutional purposes. ${ }^{89}$ There are also several judgments of the high court and at least one of the Supreme Court of Appeal that support this view. ${ }^{90}$

Moreover, the Constitutional Court has on more than one occasion recognised personal rights as property for the purposes of section 25(1). The best example is National Credit Regulator $v$ Opperman, ${ }^{91}$ where the Court explained that, although a personal right is not a real right in property like ownership, the property clause does not deal with ownership but with property. The Court had previously assumed without finding that a claim for

FNB para 51. Also see para 100(e), where it is implied that rights less than ownership are also protected.

Van der Walt Constitutional Property 140; Badenhorst, Pienaar and Mostert Law of Property 536; Roux "Property" para 46(b). Also see Ex parte Optimal Property Solutions 20032 SA 136 (C) para 19, where a servitude was classified as "property"; and Agri SA v Minister for Minerals and Energy 20134 SA 1 (CC) paras 32-44, where mineral rights were classified as "property".

Commentators agree that all (limited) real rights recognised by common law should be protected as constitutional property: see eg Van der Walt Constitutional Property 140; Roux "Property" para 46.3(b); Mostert and Badenhorst "Property" para 3FB6.2.2; Badenhorst, Pienaar and Mostert Law of Property 536; Brits Mortgage Foreclosure para 6.4.2.2; Brits Real Security 99. See also Gainsford $v$ Tiffski Property Investments (Pty) Ltd 20123 SA 35 (SCA) paras 42-47, where it seems as if the Supreme Court of Appeal would have been willing to regard a mortgage as "property" were it not for the fact that in casu the mortgage was ab initio void due to s 34(1) of the Insolvency Act 24 of 1936.

Van der Walt Constitutional Property 96; Roux and Davis "Property" para 20.3; Mostert and Badenhorst "Property" para 3FB6.1.2, 6.2.2; Roux "Property" para 46.3(a), (c); Marais 2016 TSAR 581; Marais 2014 SALJ 217-222; Brits Real Security 11; Brits 2013 PELJ 465; Brits Mortgage Foreclosure para 6.4.2.3. See also Otto and Otto National Credit Act Explained 2 ${ }^{\text {nd }}$ ed 115 and n 158; Scott 2010 THRHR 623, 636; Cloete 2003 Obiter 71, 80-81.

See eg FirstRand Bank v BL Smith (24205/08) WLD (31 October 2008) (copy on file with author) para 25; Rossouw v FirstRand Bank Ltd 20106 SA 439 (SCA) paras 17, 42; African Banking Corporation of Botswana Ltd $v$ Kariba Furniture Manufacturers (Pty) Ltd 20136 SA 471 (GNP) para 45; Opperman v Boonzaaier 2012 ZAWCHC 27 (17 April 2012) para 18; Troskie v Von Holdt 2013 ZAECGHC 31 (11 April 2013) para 37.

91 National Credit Regulator v Opperman 20132 SA 1 (CC) (hereafter Opperman) para 61. 
loss of earning capacity qualifies as "property"92 and thus in Opperman the Court explained that "the recognition of the right to restitution of money paid, based on unjustified enrichment, as property under section 25(1) is logical and realistic". ${ }^{93}$ By implication the Court also agreed with the main reasons given by the court a quo ${ }^{94}$ for why the restitution claim amounted to property, namely that this personal right is a concrete asset in the credit provider's estate, that it has a monetary value, and that it is transferable. ${ }^{95}$ The Court therefore concluded that the enrichment claim in casu qualified as "property" for the purposes of section 25 of the Constitution. ${ }^{96}$ Another example is Chevron $v$ Wilson, ${ }^{97}$ where the Constitutional Court accepted that moneys paid to a credit provider qualify as "property" in the credit provider's hands.

Therefore, from case law it is abundantly clear that a personal right that originates in unjustified enrichment amounts to "property" for constitutional purposes. By analogy, one can therefore comfortably accept that a contractual right with a monetary value qualifies as "property" too. This prospect is strengthened by the fact that the Constitutional Court has also held that personal rights under a liquor licence - a category far more controversial than contractual claims - qualify as "property" for constitutional purposes. ${ }^{98}$

\subsection{The effects of the remedies as "deprivation" of property}

Assuming then that the contractual and security rights of credit providers qualify as property, the next question is whether the granting of any of the reckless credit remedies involves a deprivation of such property. In other words, if a setting-aside, suspension or restructuring order is granted, is the credit provider "deprived" of property?

In First National Bank $v$ Commissioner of SARS the Constitutional Court accepted that deprivation is a wide concept that includes "any interference with the use, enjoyment or exploitation of private property". ${ }^{99}$ In Mkontwana

\footnotetext{
92 Law Society of South Africa v Minister of Transport 20112 BCLR 150 (CC) para 84. 93 Opperman para 63, citing Van der Walt Constitutional Property 115-116, 141-142.

$94 \quad$ Opperman v Boonzaaier 2012 ZAWCHC 27 (17 April 2012) para 18.

$95 \quad$ Opperman para 57. Opperman para Para 64. Also see Cherangani Trade and Invest 107 (Pty) Ltd v Mason 201111 BCLR 1123 (CC) para 8; Cool Ideas 1186 CC v Hubbard 20144 SA 474 (CC) para 38. Chevron SA (Pty) Ltd v Wilson t/a Wilson's Transport 201510 BCLR 1158 (CC) para 16 (hereafter Chevron). Also see para 18.

$98 \quad$ Shoprite Checkers (Pty) Ltd v MEC for Economic Development, Eastern Cape 2015 6 SA 125 (CC) paras 57-72. See further Marais 2016 TSAR 576-592; Rautenbach 2015 TSAR 825-829; Slade 2015 JQR para 2.1. FNB para 57.
} 
v Nelson Mandela Metropolitan Municipality ${ }^{100}$ the Court seemingly regressed from this broad definition by finding that it needs to be a substantive interference that goes beyond the normal restrictions on property in an open and democratic society. However, in later judgments the Court appeared to have accepted the wider definition again, ${ }^{101}$ and in Opperman ${ }^{102}$ the Court confirmed that, for the interference to qualify as a deprivation, it must at least be "significant enough to have a legally relevant impact" on the affected rights.

For the present purposes, it is in my reasonably undisputed view that, when granted, each of the reckless credit remedies deprives the credit provider of its property. Although the degree of interference differs, both the settingaside, suspension and restructuring remedies clearly entail legally significant interferences with or modifications of the enjoyment and/or enforcement of the credit provider's rights under the credit agreement.

\subsection{The arbitrariness test}

It is important to emphasise that, just because the creditor's rights are regarded as "property" and just because the undoing or modification of such rights qualifies as a "deprivation", this does not necessarily indicate that the statutorily authorised restriction is constitutionally problematic. A deprivation of property is never unconstitutional per se. The regulation (or deprivation) of the use and enjoyment of property in the public interest is a normal part of life in a democratic society, and thus it must be emphasised that only an "arbitrary" deprivation of property will violate the right contained in section 25(1).

The leading definition of the arbitrariness test is found in the Constitutional Court's FNB judgment. The Court found that the deprivation is arbitrary if the law "does not provide sufficient reason for the particular deprivation in question or is procedurally unfair". ${ }^{103}$ Consequently, there are two forms of

100 Mkontwana v Nelson Mandela Metropolitan Municipality; Bissett v Buffalo City Municipality; Transfer Rights Action Campaign v Member of the Executive Council for Local Government and Housing, Gauteng 20051 SA 530 (CC) para 32. Also see Chevron paras 17-19.

101 See eg Reflect-All 1025 CC v MEC for Public Transport, Roads and Works, Gauteng Provincial Government 20096 SA 391 (CC) para 36; Offit Enterprises (Pty) Ltd v Coega Development Corporation (Pty) Ltd 20111 SA 293 (CC) paras 38-39, 41; Tshwane City v Link Africa 20156 SA 440 (CC) para 58; and see further Van der Walt Constitutional Property 206-209.

102 Opperman para 66. Also compare South African Diamond Producers Organisation $\checkmark$ Minister of Minerals and Energy 20176 SA 331 (CC) paras 42-48.

103 FNB para 100. 
arbitrariness: substantive arbitrariness (insufficient reason) and procedural arbitrariness (procedurally unfair).

Although it is not clear what exactly is meant with procedural arbitrariness, ${ }^{104}$ in both Opperman and Chevron, for instance, the Constitutional Court found that the relevant deprivations were procedurally arbitrary because the statutory provisions in question did not afford the court a discretion, based on the facts of the case, whether or not to uphold the deprivation. ${ }^{105}$ For the present purposes it can therefore be accepted that the provisions pertaining to the remedies for reckless credit are probably not procedurally arbitrary. The reason for this is that, in each instance, the court (or Tribunal) has a discretion as to whether or not to make the order. It also has a discretion regarding the content of each order - for instance the time period of the suspension and the extent of the setting aside. Regarding the latter remedy, the court is also required to make an order that is just and reasonable in the circumstances, which affords the court a large leeway to ensure that the order is justifiable on the facts of each case. Moreover, the restructuring remedy allows for a large degree of flexibility with respect to how the obligations can be rearranged. In other words, the fact that the court has oversight and wide discretionary powers when it comes to these remedies indicates that the procedural fairness requirement should rarely cause problems. The way the discretion is exercised is another matter, which relates to the second leg of the arbitrariness test.

The substantive arbitrariness test requires that the deprivation in question must have a sufficient reason. This test is very flexible and context sensitive, since the Court in FNB emphasised that it must "be decided on all the relevant facts of each particular case". ${ }^{106}$ Basically, one must evaluate "the relationship between the means employed, namely the deprivation in question and the ends sought to be achieved, namely the purpose of the law in question". ${ }^{107}$ In this respect one must consider a complexity of relationships, such as those between the purpose of the deprivation and the person whose property is affected; between the purpose of the deprivation and the nature of the property; and between the purpose and extent of the deprivation. ${ }^{108}$ The Court also indicated that the type of property right involved (ownership versus a lesser right) as well as the extent of the deprivation (embracing all versus only some of the incidents of the right)

\footnotetext{
104 Compare Van der Walt 2012 Stell LR 88-94.

105 Opperman paras 69, 76; Chevron paras 22-24.

$106 \quad F N B$ para $100(\mathrm{~h})$.

$107 \quad$ FNB para $100(\mathrm{a})$.

$108 \quad F N B$ para $100(\mathrm{~b})-(\mathrm{d})$.
} 
could impact on how compelling the purpose of the deprivation would have to be to pass the arbitrariness test. ${ }^{109}$

In other words, not only must the deprivation be buttressed by a valid public purpose, but in each individual case there must also be a sufficient relationship between this purpose and the effect that the deprivation has on the person whose property is affected. ${ }^{110}$ Depending on the facts, the level of scrutiny will then be somewhere on a continuum between a mere rationality test and a proportionality test almost as strict as the one contemplated in section 36 of the Constitution. ${ }^{111}$

It is easy to identify and justify the purpose behind the reckless credit remedies. The NCA expressly seeks to discourage reckless lending and the ills that accompany it. Preventing and remedying reckless credit is also of socio-economic significance, since unaffordable loans can cause social and economic devastation for consumers, their families and society at large. Preventing the granting of unaffordable loans also contributes to the protection of consumers' inherent human dignity ${ }^{112}$ and it instils prudential integrity in the broader financial industry. Hence, the first intended effect of these remedies is to discourage credit providers from concluding reckless credit agreements with consumers and, to this effect, to encourage them to do the required pre-agreement assessments. ${ }^{113}$ The second intended effect is to provide debt relief for consumers who have suffered prejudice as a result of entering into a reckless credit agreement.

Although it is true that the reckless credit remedies have the effect of penalising the reckless credit provider, ${ }^{114}$ in my view this effect is only incidental and not the prime purpose of these remedies. Instead, it is contended that the main aim is to bring relief to consumers who are overindebted as a result of being granted credit in a reckless fashion. There are other ways to "punish" the responsible credit provider, such as with an

\footnotetext{
109 FNB para $100(\mathrm{e})-(\mathrm{f})$.

110 Compare the analysis by Brits 2013 PELJ 446-457 of the high court's and the Constitutional Court's application of the arbitrariness test in Opperman.

111 FNB para $100(\mathrm{~g})$.

112 See $\mathrm{S} 10$ of the Constitution.

113 See eg ABSA Bank v Coe Family Trust 20123 SA 184 (WCC) 188H-I; Campher) para 15; Plastomark (Pty) Ltd v CK Injection Moulders CC; In re: Ultrapolymers (Pty) Ltd v CK Injection Moulders CC 2015 ZAWCHC 129 (1 September 2015) para 14. Also see ABSA Bank Limited $v$ Potgieter 2017 ZAECPEHC 8 (31 January 2017) para 60.

114 Van Heerden and Boraine 2011 De Jure 393; Vessio 2009 TSAR 281.
} 
administrative fine imposed by the Tribunal, ${ }^{115}$ or by suspending or cancelling its registration as a credit provider. ${ }^{116}$

In other words, there can hardly be any doubt about the general validity of the purpose behind the NCA's reckless credit provisions. However, the question is whether, in each individual case, there is a sufficient relationship between the purpose of the remedy and the effect thereof on the particular credit provider. Does the Act allow enough flexibility in the implementation of these remedies so that, in individual cases, arbitrary outcomes can be avoided? To my mind, a case cannot be made to declare the provisions in the NCA, which stipulate for these remedies, unconstitutional for permitting arbitrary deprivation of property. The fact that the NCA provides a wide discretion for the courts, not only when it comes to whether a remedy should be granted but also when it comes to the content of the remedies, indicates that the Act is nuanced enough to avoid both procedural and substantive arbitrariness.

\section{Applying the arbitrariness test to the remedies}

Although the sections in the NCA that provide for the reckless credit remedies do not fall short of section 25(1) of the Constitution in general, it is important that these provisions are applied in such a manner that arbitrary outcomes are avoided in individual cases - that a constitutionally appropriate balance is achieved between the interests of the credit provider and consumer in question. Regarding the court's discretion, the substantive arbitrariness test can in fact assist courts when deciding whether to grant a remedy as well as on the content of the remedy. In each case a court should ascertain what the effect on the credit provider would be and then ask whether such an effect is justified by the purpose of the remedy.

A general proposition is that the effect of any remedy should go only as far as is necessary to rectify the consequences of the reckless credit agreement - of the credit provider's prohibited behaviour. If it stays within such bounds, the deprivation of property has a sufficient reason and hence it is not arbitrary. But if it goes further than necessary, it becomes arbitrary because the effect on the credit provider is no longer sufficiently linked to the prejudice that was caused by the credit provider's actions. Take a simple example: If a credit provider grants a reckless loan of R100 000 and because thereof the consumer becomes over-indebted with R40 000, it

\footnotetext{
115 Section 151 of the NCA.

116 Section 57 of the NCA.
} 
would be arbitrary for a court to set aside the entire R100 000. Accordingly, the court should consider all factors, including the financial situation, to determine the appropriate remedy. Courts should avoid granting generic remedies, and should rather ensure that the content of each remedy is tailor made to the facts of the case before it. In view of the serious consequences that these remedies might have - especially the setting-aside remedy courts should do a careful analysis and provide detailed reasons for the order they hand down. Since a deprivation of property takes place, the court is mandated to ensure that there is a sufficient reason for the effect that the remedy will have on the credit provider.

Furthermore, it is suggested that the substantive arbitrariness test can help answer some of the points that have been raised by authors with respect to the uncertainties that surround the reckless credit remedies. As explained above, the main uncertainties that have come to light from academic commentary are as follows:

a) How should one decide between the suspension and setting-aside remedies, and in the latter instance, how should one decide between a full and partial setting aside?

b) What happens if either or both parties have performed under the agreement?

c) What is the effect on the credit provider's security?

Boraine and Van Heerden, have considered these questions and have made some good suggestions. ${ }^{117}$ I should like to add that the property clause's arbitrariness test can assist in answering these questions. ${ }^{118}$ Essentially, whenever a court is called upon to formulate a remedy in the reckless credit context, it would have to do so in a way that avoids any arbitrary outcomes.

Inherent in this test, the court should consider whether and to what extent either of the parties have already performed under the agreement. The value of such performances should then be taken into account when the appropriate remedy is formulated. Consequently, matters of restitution should not be left to future litigation surrounding unjustified enrichment. As the court in Standard Bank v Kelly ${ }^{119}$ commented:

117 Boraine and Van Heerden 2010 THRHR 651, 652-656; Van Heerden and Boraine 2011 De Jure 402-408, 414-415; Van Heerden "Over-indebtedness and Reckless Credit" para 11.5.7.1.

118 Also see Brits Mortgage Foreclosure para 6.4.6.

119 Kelly 8. 
The court is unlikely to make any order relieving the consumer of its obligations if the result would be the unjust enrichment of the consumer at the expense of the credit provider.

This comment is illuminating because it suggests that, when the court decides on the remedy, it should make accommodation for the fact that the remedy should not unjustifiably enrich the consumer. This supports my proposal that the court should, when formulating a just and reasonable remedy, consider the performances that have been rendered already.

A similar approach would apply to the creditor's security. If it is assumed that the property remains with the consumer, then to avoid arbitrary outcomes, the content of the remedy must accommodate the monetary benefits enjoyed by the consumer as a result of having his property freed from the credit provider's security right, for example.

The arbitrariness test can also help to decide between the suspension and setting-aside remedies, as well as to decide on the extent of the settingaside remedy. Broadly speaking, it will probably be arbitrary to grant a certain remedy if another remedy could achieve the same purpose in a way that imposes a lesser deprivation of property. Accordingly, to my mind the suspension remedy should always be the first choice, and the setting-aside remedy should only be an option if a suspension cannot provide the necessary relief to the consumer. Setting the consumer's obligations aside should not be the default course of action. In fact, courts should probably only resort to it in extreme cases. ${ }^{120}$

The same reasoning can apply when choosing the extent of a setting-aside remedy. The first choice should not be a full setting aside, since a less invasive option should be considered first. A full setting aside should be ordered only if it is truly necessary to rectify the damage done by the credit provider's reckless conduct.

In De Beer the court unfortunately did not spend a lot of time explaining the reason for its remedy. The judge merely stated that his choice of a full setting-aside remedy was influenced by three factors: ${ }^{121}$

a) the clear extent of the recklessness (the affordability assessment was irrational in that the surety's income was taken into account to determine the consumer's credit worthiness);

\footnotetext{
$120 \quad$ Also see Otto and Otto National Credit Act Explained $4^{\text {th }}$ ed 91.

121 De Beer para 65.
} 
b) the advanced age of the consumers; ${ }^{122}$ and

c) the fact that the property sought to be declared executable was the consumers' only home.

Interestingly, two of the reasons given by the court in De Beer are external to the express provisions of the NCA, which do not list the consumer's age or his home situation as factors when formulating a remedy. Of course, such issues should be included in the "just and reasonable" standard required for setting-aside remedies. Also, the extent of the recklessness, and thus the level of bad faith or turpitude on the credit provider's part should naturally be a strong contributing factor. However, other than these factors, it does not seem as if the court gave much (if any) attention to the finer details of the consequences of this full setting-aside order.

Because the performances already rendered did not appear to play a part in the court's determination, it seems instinctively that the consumers got an over-the-top windfall that is disproportionate to the prejudice they truly suffered at the hands of the credit provider's conduct. Also, in view of the facts revealed in the judgment, can it truly be said that the credit provider in this case deserves this momentous sanction in comparison to its level of turpitude and if measured against the prejudice suffered by the consumer? It is not suggested that a setting-aside order was inappropriate as such, but I am not convinced that a full setting aside of the consumer's obligations was just and reasonable on the facts of the case. To my mind, a strong case can also be made that the effects on the credit provider amounted to an arbitrary deprivation of property.

It can also be mentioned that a consumer mortgage agreement will very often comprise of a home loan. It is trite that this factor has important implications for mortgage foreclosure proceedings due to the constitutional protection of housing rights. ${ }^{123}$ It is not necessary to extrapolate on this perspective here, ${ }^{124}$ but suffice it to say that, in appropriate circumstances, the fact that the reckless credit agreement involves a home could influence the court's decision when formulating the appropriate remedy, as was evidently the case in De Beer.

\footnotetext{
122 Also Benade $v$ ABSA Bank Limited 2014 ZAWCHC 84 (16 May 2014) para 36.

123 Section 26 Constitution; High Court Rule 46(1)(a)(ii); Jaftha v Schoeman; Van Rooyen v Stoltz 20052 SA 140 (CC); Gundwana v Steko Development 20113 SA 608 (CC).

124 See Brits Real Security 68-103 and the other sources cited there.
} 


\section{Conclusion}

The purpose of this article is not to create scepticism regarding the granting of the reckless credit remedies, but to highlight the importance of not making snap judgments on what remedy to grant. ${ }^{125}$ More specifically, the main argument is that section 25(1) of the Constitution, and the principles underlying it, should play a role in formulating the appropriate remedy in each individual case. Because a credit provider's contractual claim to repayment of the loan as well as its real security right qualify as "property" and because each of the remedies potentially "deprives" the credit provider of his rights, it is important that the arbitrariness test should be met when these remedies are granted. All factors must be considered and there must be a sufficient reason for the limitation imposed on the credit provider's rights, which means that there should be a satisfactory relationship between the purpose of the remedy (to discourage reckless credit and to relieve the consumer) and the effects on the credit provider. If the purpose and effect are out of proportion, the arbitrariness test might not be satisfied.

As a rule of thumb, a reckless credit remedy should do no more than to rectify the prejudice suffered by the consumer due to the credit provider's conduct. One way to quantify the consumer's prejudice is the amount of the over-indebtedness that was caused by the reckless credit, but it can include other things like the impact on his dignity. The point is that the remedy should be tailored in such a way that the prejudice suffered by the consumer is removed. Anything more than that should be viewed with suspicion, otherwise the shift in patrimony from the credit provider to the consumer could be unjustified and unconstitutional.

\section{Bibliography}

\section{Literature}

Badenhorst, Pienaar and Mostert Law of Property

Badenhorst PJ, Pienaar JM and Mostert H Silberberg and Schoeman's The Law of Property $5^{\text {th }}$ ed (LexisNexis Durban 2006)

125 See eg Mbatha para 37, where the court warned against "[an] overcritical armchair approach by the courts towards credit providers when evaluating reckless credit, or the imposition of excessive penalties upon lenders who have recklessly allowed credit". 
Boraine and Van Heerden 2010 THRHR

Boraine A and Van Heerden C "Some Observations Regarding Reckless Credit in terms of the National Credit Act 34 of 2005" 2010 THRHR 650-656

Brits Mortgage Foreclosure

Brits R Mortgage Foreclosure under the Constitution: Property, Housing and the National Credit Act (LLD-thesis Stellenbosch University 2012)

Brits 2013 PELJ

Brits R "Arbitrary Deprivation of Unregistered Credit Provider's Right to Claim Restitution of Performance Rendered: Opperman $v$ Boonzaaier (24887/2010) 2012 ZAWCHC 27 (17 April 2012) and National Credit Regulator v Opperman 20132 SA 1 (CC)" 2013 PELJ 422-470

Brits Real Security

Brits R Real Security Law (Juta Cape Town 2016)

Cloete 2003 Obiter

Cloete R "Die Plek en Rol van Onstoflike Sake in die Nuwe Suid-Afrikaanse Sakereg: 'n Kritiese Oorsig" 2003 Obiter 65-86

Coetzee Comparative Reappraisal

Coetzee H A Comparative Reappraisal of Debt Relief Measures for Natural Person Debtors in South Africa (LLD-thesis University of Pretoria 2015)

Kelly-Louw 2008 SA Merc LJ

Kelly-Louw $M$ "The Prevention and Alleviation of Consumer Overindebtedness" 2008 SA Merc LJ 200-226

Kelly-Louw $2010 \mathrm{JQR}$

Kelly-Louw M "Credit Law" 2010 (2) JQR para 2.1

Kelly-Louw Consumer Credit Regulation

Kelly-Louw M Consumer Credit Regulation in South Africa (Juta Cape Town 2012)

Kelly-Louw "Consumer Credit"

Kelly-Louw M "Consumer Credit" in Joubert WA and Faris JA (eds) The Law of South Africa vol $83^{\text {rd }}$ ed (LexisNexis Durban 2014) paras 1-227

Kelly-Louw 2014 SA Merc LJ

Kelly-Louw M "A Credit Provider's Complete Defence Against a Consumer's Allegation of Reckless Lending" 2014 SA Merc LJ 24-59 
Koekemoer $2016 J Q R$

Koekemoer MM "Credit Law" 2016 (2) JQR para 2.1

Marais 2014 SALJ

Marais EJ "The Constitutionality of Section 89(5)(c) of the National Credit Act under the Property Clause: National Credit Regulator v Opperman \& Others" 2014 SALJ 215-233

Marais 2016 TSAR

Marais EJ "Expanding the Contours of the Constitutional Property Concept: Shoprite Checkers (Pty) Ltd v MEC for Economic Development, Eastern Cape 2015 (6) SA 125 (CC)" 2016 TSAR 576-592

Mostert and Badenhorst "Property"

Mostert $\mathrm{H}$ and Badenhorst PJ "Property and the Bill of Rights" in Mokgoro $\mathrm{Y}$ and Tlakula $\mathrm{P}$ (eds) Bill of Rights Compendium $34^{\text {th }}$ Service Issue (LexisNexis Durban 2014) ch 3FB

Otto 2017 TSAR

Otto JM "Die Impak van die Nasionale Kredietwet op die Sakereg en Saaklike Sekerheid" 2017 TSAR 167-175

Otto and Otto National Credit Act Explained $2^{\text {nd }}$ ed

Otto JM and Otto R-L The National Credit Act Explained $2^{\text {nd }}$ ed (LexisNexis Durban 2010)

Otto and Otto National Credit Act Explained $4^{\text {th }}$ ed

Otto JM and Otto R-L The National Credit Act Explained $4^{\text {th }}$ ed (LexisNexis Durban 2016)

Rautenbach 2015 TSAR

Rautenbach IM "Dealing with the Social Dimensions of the Right to Property in the South African Bill of Rights" 2015 TSAR 822-833

Renke 2011 THRHR

Renke S "Measures in South African Consumer Credit Legislation Aimed at the Prevention of Reckless Lending and Over-indebtedness: An Overview against the Background of Recent Developments in the European Union" 2011 THRHR 208-229 
Renke 2015 LitNet

Renke S "Die Nuwe Bekostigbaarheidsassessering-regulasies ingevolge die Nasionale Kredietwet 34 van 2005 van Naderby Beskou" 2015 LitNet Akademies 432-454

Renke, Roestoff and Haupt 2007 Obiter

Renke S, Roestoff M and Haupt F "The National Credit Act: New Parameters for the Granting of Credit in South Africa" 2007 Obiter 229-270

Roux "Property"

Roux T "Property" in Woolman S, Bishop M and Brickhill J (eds) Constitutional Law of South Africa Vol $32^{\text {nd }}$ ed Original Service (Juta Cape Town 2003) ch 46

Roux and Davis "Property"

Roux T and Davis D "Property" in Cheadle MH, Davis DM and Haysom NRL (eds) South African Constitutional Law: The Bill of Rights $2^{\text {nd }}$ ed $21^{\text {st }}$ Service Issue (LexisNexis Durban 2016) ch 20

Scott 2010 THRHR

Scott S "Vorderingsregte as Onliggaamlike Sake: Waarom nie?" 2010 THRHR 629-637

Slade $2015 J Q R$

Slade BV "Constitutional Property Law" 2015 (3) JQR para 2.1

Sonnekus 2016 TSAR

Sonnekus JC "Roekelose Krediet en Saaklike Sekerheid: Wat van die Ongegronde Verryking?" 2016 TSAR 351-362

Stoop 2009 SA Merc LJ

Stoop PN "South African Consumer Credit Policy: Measures Indirectly Aimed at Preventing Consumer Over-indebtedness" 2009 SA Merc LJ 365386

Stoop and Kelly-Louw 2011 PELJ

Stoop PN and Kelly-Louw M "The National Credit Act regarding Suretyships and Reckless Lending" 2011 PELJ 67-96

Van der Walt Constitutional Property

Van der Walt AJ Constitutional Property Law $3^{\text {rd }}$ ed (Juta Cape Town 2011) 
Van der Walt 2012 Stell $L R$

Van der Walt AJ "Procedurally Arbitrary Deprivation of Property" 2012 Stell LR 88-94

Van Heerden "Over-indebtedness and Reckless Credit"

Van Heerden C "Over-indebtedness and Reckless Credit" in Scholtz JW et al (eds) Guide to the National Credit Act $8^{\text {th }}$ revised service (LexisNexis Durban Jun 2016) ch 11

Van Heerden and Boraine 2011 De Jure Van Heerden CM and Boraine A "The Money or the Box: Perspectives on Reckless Credit in terms of the National Credit Act 34 of 2005" 2011 De Jure 392-415

Van Heerden and Renke 2015 Int Insolv Rev

Van Heerden $C$ and Renke $S$ "Perspectives on the South African Responsible Lending Regime and the Duty to Conduct Pre-agreement Assessment as a Responsible Lending Practice" 2015 Int Insolv Rev 67-95

Vessio 2006 THRHR

Vessio ML "The Preponderance of the Reckless Consumer: The National Credit Bill 2005" 2006 THRHR 649-657

Vessio 2009 TSAR

Vessio ML "Beware the Provider of Reckless Credit" 2009 TSAR 274-289

\section{Case law}

ABSA Bank Limited v Kganakga 2016 ZAGPJHC 59 (18 March 2016)

ABSA Bank Limited v Pereira 2015 JDR 1208 (GJ)

ABSA Bank Limited v Potgieter 2017 ZAECPEHC 8 (31 January 2017)

ABSA Bank Ltd v De Beer 20163 SA 432 (GP)

ABSA Bank Ltd v Malherbe 2013 ZAFSHC 78 (16 May 2013)

ABSA Bank Ltd v Schneider 2015 ZAGPPHC 855 (3 December 2015)

ABSA Bank v Coe Family Trust 20123 SA 184 (WCC)

Africa Bank Limited v Greyling 2014 ZAGPJHC 315 (7 November 2014) 
African Banking Corporation of Botswana Ltd $v$ Kariba Furniture Manufacturers (Pty) Ltd 20136 SA 471 (GNP)

Agri SA v Minister for Minerals and Energy 20134 SA 1 (CC)

Benade v ABSA Bank Limited 2014 ZAWCHC 84 (16 May 2014)

Cherangani Trade and Invest 107 (Pty) Ltd v Mason 201111 BCLR 1123 (CC)

Chevron SA (Pty) Ltd v Wilson t/a Wilson's Transport 201510 BCLR 1158 (CC)

Cool Ideas 1186 CC v Hubbard 20144 SA 474 (CC)

Ex parte Optimal Property Solutions CC 20032 SA 136 (C)

First National Bank of SA Ltd t/a Wesbank v Commissioner, South African Revenue Service; First National Bank of SA Ltd t/a Wesbank v Minister of Finance 20024 SA 768 (CC)

FirstRand Bank Limited v Van Coller 2017 ZAGPPHC 85 (8 March 2017)

FirstRand Bank v BL Smith (24205/08) WLD (31 October 2008) (copy on file with author)

Gainsford v Tiffski Property Investments (Pty) Ltd 20123 SA 35 (SCA)

Gundwana v Steko Development 20113 SA 608 (CC)

Jaftha v Schoeman; Van Rooyen v Stoltz 20052 SA 140 (CC)

Kilburn v Estate Kilburn 1931 AD 501

Land \& Agricultural Development Bank of South Africa Ltd v Bosch 2014 ZAGPJHC 130 (30 May 2014)

Law Society of South Africa v Minister of Transport 20112 BCLR 150 (CC) Maria $v$ Nedbank Limited; In re: Nedbank Limited v Foley 2016 ZAGPPHC 669 (4 August 2016)

Mercantile Bank Ltd v Hajat 2013 ZAGPJHC 134 (9 May 2013) 
Mkontwana v Nelson Mandela Metropolitan Municipality; Bissett v Buffalo City Municipality; Transfer Rights Action Campaign $v$ Member of the Executive Council for Local Government and Housing, Gauteng 20051 SA 530 (CC)

Mofuta v SA Taxi Securitisation (Pty) Ltd, In re: SA Taxi Securitisation (Pty) Ltd v Mofuta 2013 ZAFSHC 95 (20 June 2013)

National Credit Regulator v Opperman 20132 SA 1 (CC)

Nedbank Limited v Schoeman 2016 ZAGPJHC 142 (2 June 2016)

Offit Enterprises (Pty) Ltd v Coega Development Corporation (Pty) Ltd 2011 1 SA 293 (CC)

Opperman v Boonzaaier 2012 ZAWCHC 27 (17 April 2012)

Plastomark (Pty) Ltd v CK Injection Moulders CC; In re: Ultrapolymers (Pty) Ltd v CK Injection Moulders CC 2015 ZAWCHC 129 (1 September 2015)

Reflect-All 1025 CC v MEC for Public Transport, Roads and Works, Gauteng Provincial Government 20096 SA 391 (CC)

Rossouw v FirstRand Bank Ltd 20106 SA 439 (SCA)

SA Taxi Development Finance (Pty) Ltd v Mokolobe 2013 ZAGPJHC 198 (11 June 2013)

SA Taxi Securitisation (Pty) Ltd v Campher 2012 ZAECGHC 9 (24 February 2012)

SA Taxi Securitisation (Pty) Ltd v Chesane 20106 SA 557 (GSJ)

SA Taxi Securitisation (Pty) Ltd v Mbatha and Two Similar Cases 20111 SA 310 (GSJ)

SA Taxi Securitisation (Pty) Ltd v Melaphi 2014 ZAWCHC 47 (2 April 2014)

SA Taxi Securitisation (Pty) Ltd v Nako 2010 ZAECBHC 4 (8 June 2010)

SA Taxi Securitisation (Pty) Ltd v Xolile 2012 JOL 29510 (ECM)

Shoprite Checkers (Pty) Ltd v MEC for Economic Development, Eastern Cape 20156 SA 125 (CC) 
South African Diamond Producers Organisation v Minister of Minerals and Energy 20176 SA 331 (CC)

Standard Bank of South Africa Limited v Dlamini 2016 ZAGPPHC 26 (22 January 2016)

Standard Bank of South Africa Ltd v Kelly 2011 ZAWCHC 1 (25 January 2011)

Thienhaus v Metje \& Ziegler Ltd 19653 SA 25 (A)

Toyota Financial Services South Africa v Mohlabi 2015 ZAFSHC 178 (10 September 2015)

Troskie v Von Holdt 2013 ZAECGHC 31 (11 April 2013)

Tshwane City v Link Africa 20156 SA 440 (CC)

University of Stellenbosch Legal Aid Clinic $v$ Minister of Justice and Correctional Services 20166 SA 596 (CC)

Wiese v ABSA Bank Limited 2017 ZAWCHC 12 (24 February 2017)

\section{Legislation}

Constitution of the Republic of South Africa, 1996

Insolvency Act 24 of 1936

National Credit Act 34 of 2005

National Credit Amendment Act 19 of 2014

Uniform Rules of Court: Rules Regulating the Conduct of the Proceedings of the Several Provincial and Local Divisions of the High Court of South Africa (cited as "High Court Rule")

\section{Internet sources}

SAPA 2010 http://www.fin24.com/PersonalFinance/Money-Clinic/Absaguilty-of-reckless-lending-20100430

South African Press Association 2010 Absa Guilty of Reckless Lending http://www.fin24.com/PersonalFinance/Money-Clinic/Absa-guilty-of-

reckless-lending-20100430 accessed 12 June 2017 


\section{List of Abbreviations}

Int Insolv Rev

JQR

NCA

PELJ

SA Merc LJ

SALJ

SAPA

Stell LR

THRHR

TSAR
International Insolvency Review

Juta's Quarterly Review

National Credit Act

Potchefstroom Electronic Law Journal

South African Mercantile Law Journal

South African Law Journal

South African Press Association

Stellenbosch Law Review

Tydskrif vir Hedendaagse RomeinsHollandse Reg

Tydskrif vir die Suid-Afrikaanse Reg 